\title{
A new psammophilic species of the genus Diacyclops (Crustacea: Cyclopoida) from the littoral zone of Lake Baikal (East Siberia)
}

\author{
Natalya G. Sheveleva1, Oleg A. Timoshkin, \\ Viacheslav N. Aleksandrov, Ekaterina P. Tereza
}

Limnological Institute of Siberian Branch of Russian Academy of Sciences, Ulan-Batorskaya, 3, 664033 Irkutsk, Russia.

'e-mail: shevn@lin.irk.ru

\begin{abstract}
An illustrated description of Diacyclops zhimulevi Sheveleva et Timoshkin, sp.n. (Crustacea, Cyclopoida: Cyclopidae) is provided. The new species is widely distributed along the southwestern coast of Lake Baikal, inhabiting sandy bottoms of the shallow littoral zone. A comparison is made with the previously studied and closely related species Diacyclops eulitoralis Alekseev et Arov, 1986 from the sandy interstitial environment of Lake Baikal. The new species differs from its most closely related species $D$. eulitoralis by a combination of characters: shorter, nearly square caudal furca (furcal index 1:1 in contrast to $1: 3.5$ in D. eulitoralis), a larger number of antennular segments, and a different segment pattern of the swimming legs: 2.2/3.2/3.3/3.3 compared to 2.2/3.2/3.2/3.2 in D. eulitoralis. The armament of the distal endopodal segments of the swimming legs 1 and 2 is generally characterized by presence of a long and stout apical spine. The two species are also clearly divergent in ecology: D. eulitoralis inhabits the upper surf zone of the beach and may fairly be called an interstitial species (Alekseev \& Arov, 1986; Boxshall et al., 1993), whereas the new species colonizes sandy bottom of the littoral zone.
\end{abstract}

KEY WORDS: Diacyclops zhimulevi Sheveleva et Timoshkin, sp.n., Cyclopoida, Cyclopidae, Lake Baikal, psammon.

\section{Новый вид псаммофильного циклопа рода Diacyclops (Crustacea: Cyclopoida) из литоральной зоны озера Байкал (Восточная Сибирь)}

\author{
Н.Г. Шевелева', О.А.Тимошкин, В.Н. Александров, Е.П. Тереза \\ Лимнологический институт Сибирского Отделения РАН, Улан-Баторская, 3, Иркутск, \\ 664033, Россия. \\ Ie-mail: shevn@lin.irk.ru
}

РЕЗЮМЕ: Приведено иллюстрированное описание нового вида Diacyclops zhimulevi Sheveleva et Timoshkin, sp.n. (Crustacea, Cyclopoida: Cyclopidae), широко распространенного вдоль западного побережья Южного Байкала и населяющего песчаные грунты мелководной литорали. Даны отличительные признаки нового вида от близкого вида Diacyclops eulitoralis Alekseev et Arov, 1986, обитающего в интерстициали заплесковой зоны озера. От наиболее близкого вида D. eulitoralis, новый вид отлича- 
ется иной комбинацией признаков: более короткие, почти квадратные каудальные ветви (фуркальный индекс 1:1, против 1:3,5 у D. eulitoralis), большее число члеников на антеннуле и иная членистость плавательных ног: 2.2/3.2/3.3/3.3 по сравнению с 2.2/3.2/3.2/3.2 у D. eulitoralis. Особо обращает на себя внимание вооружение дистальных члеников эндоподитов плавательных ног 1 и 2 , для которых очень характерно наличие мощного и длинного апикального шипа. Кроме того, оба вида хорошо различаются экологически, по местообитанию. D. eulitoralis населяет верхнюю, заплесковую зону пляжа и действительно может быть назван интерстициальным видом (Алексеев, Аров, 1986; Boxshall et al., 1993), в то время как новый вид освоил песчаные грунты собственно литоральной зоны.

КЛЮЧЕВЫЕ СЛОВА: Diacyclops zhimulevi Sheveleva et Timoshkin, sp.n., Cyclopoida, Cyclopidae, Байкал, псаммон.

\section{Introduction}

The fauna of Lake Baikal is surprisingly species-rich and diverse; nearly 2638 species and subspecies are currently known (Timoshkin, 2008; Timoshkin et al., 2008). The taxon list of Baikalian cyclopoid copepods includes 43 species, with $56 \%$ being endemic (Mazepova, 1978, 2001). These crustaceans vary not only morphologically, but also ecologically. Among them are planktonic, epibenthic, and benthic species as well as species associated with other organisms, and parasitic species. Our examination of the morphology, systematics, ecology and molecular biology of the Cyclopoida of Baikal has shown that their species number is much greater than hitherto known. Some ecological groups of cyclopoids appear to be either insufficiently studied or completely unknown. Such a group is Cyclopidae living among sand grains, which includes several endemic species. The size of mature specimens (females) ranges from 0.2 to $1 \mathrm{~mm}$. Several small cyclopoids of the genera Diacyclops and Acanthocyclops have been described already from Lake Baikal (Mazepova, 1978; Flossner, 1984; Alekseev \& Arov, 1986; Boxshall et al., 1993). The smallest of these, with an adult body length not exceeding $350 \mu \mathrm{m}$, is Diacyclops eulitoralis Alekseev et Arov, 1986, which was found in the littoral zone of southwestern Lake Baikal, in the bays of Maloe More, Chivyrkuy, Barguzin and Enkhaluk (Alekseev \& Arov, 1986). The mini- mal body length of other familiar but smallsized cyclopoid species is distinctly greater: Diacyclops neglectus Flossner, $1984(980 \mu \mathrm{m})$; Acanthocyclops similis Flossner, 1984 (1280 $\mu \mathrm{m})$; Acanthocyclops improcerus Mazepova, $1978(480 \mu \mathrm{m})$; and Acanthocyclops versutus Mazepova, 1978 (600 ㅆm) (Mazepova, 1978; Flossner, 1984). Our investigations during 20062007 showed that the infauna of sandy bottoms in the lake is not restricted to the previously described D. eulitoralis, Diacyclops biceri, but also includes several tiny cyclopoids, whose body length does not exceed $500 \mu \mathrm{m}$. There are good reasons to believe that they represent a flock of endemic species being mainly new to science. The present work aims at describing a new species belonging to the genus Diacyclops, which we encountered in the shallow littoral of the southern Lake Baikal.

\section{Material and Methods}

Samples were collected from the sandy bottom manually from a depth of $0.5-0.6 \mathrm{~m}$, and from a boat at depths up to 3-4 $\mathrm{m}$, by using a net made of fine gauze ( $77 \mu \mathrm{m}$ mesh size), towing it above the ground or getting the sediment into the net as well. During the summer months cyclopoid crustaceans were found in abundance. In total, about 50 specimens (females and males) collected in 2006-2007 from the southwestern shore of Lake Baikal were examined. Copepods were photographed at full-length, both, while 


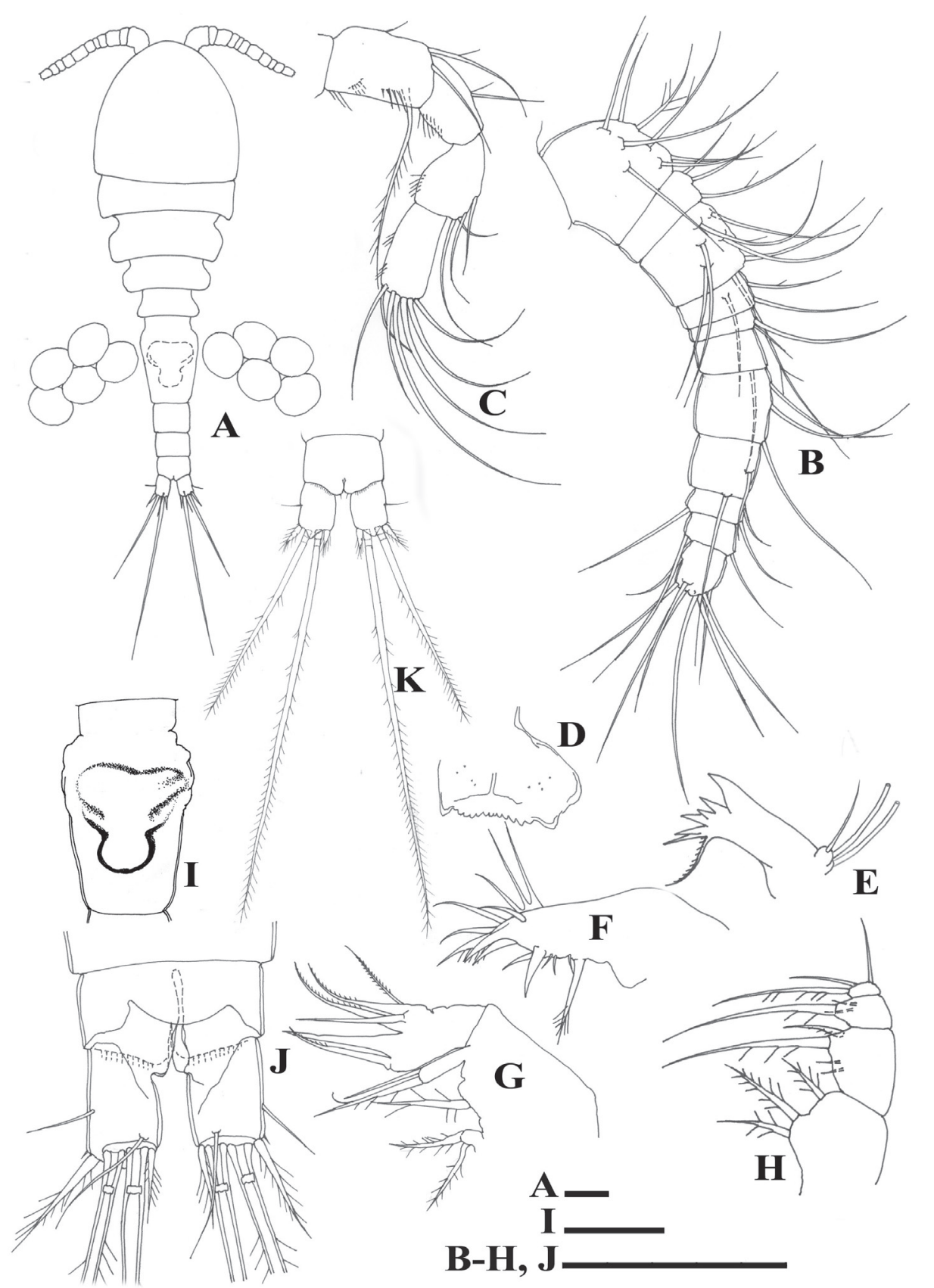

Fig. 1. Diacyclops zhimulevi sp.n. Paratype, female.

A - dorsal view; B - antennule; C - antenna; D - labrum; E - mandible; F - maxillule; $\mathrm{G}$ - maxilla; H maxilliped; I - genital segment, ventral view; J - anal somite, dorsal view; $\mathrm{K}$ - anal somite and caudal rami, ventral view. Scale bar $50 \mu \mathrm{m}$.

Рис. 1. Diacyclops zhimulevi sp.n. Паратип, самка.

А — общий вид со спиной стороны; В — антеннула; С — антенна; D — губа; Е — мандибула; F — максиллула; $\mathrm{G}$ - максилла; H - максиллярная нога; I - генитальный сегмент с брюшной стороны; J - анальный сегмент со спины; К — анальный сегмент и каудальные ветви, с брюшной стороны. Масштаб 50 мкм. 

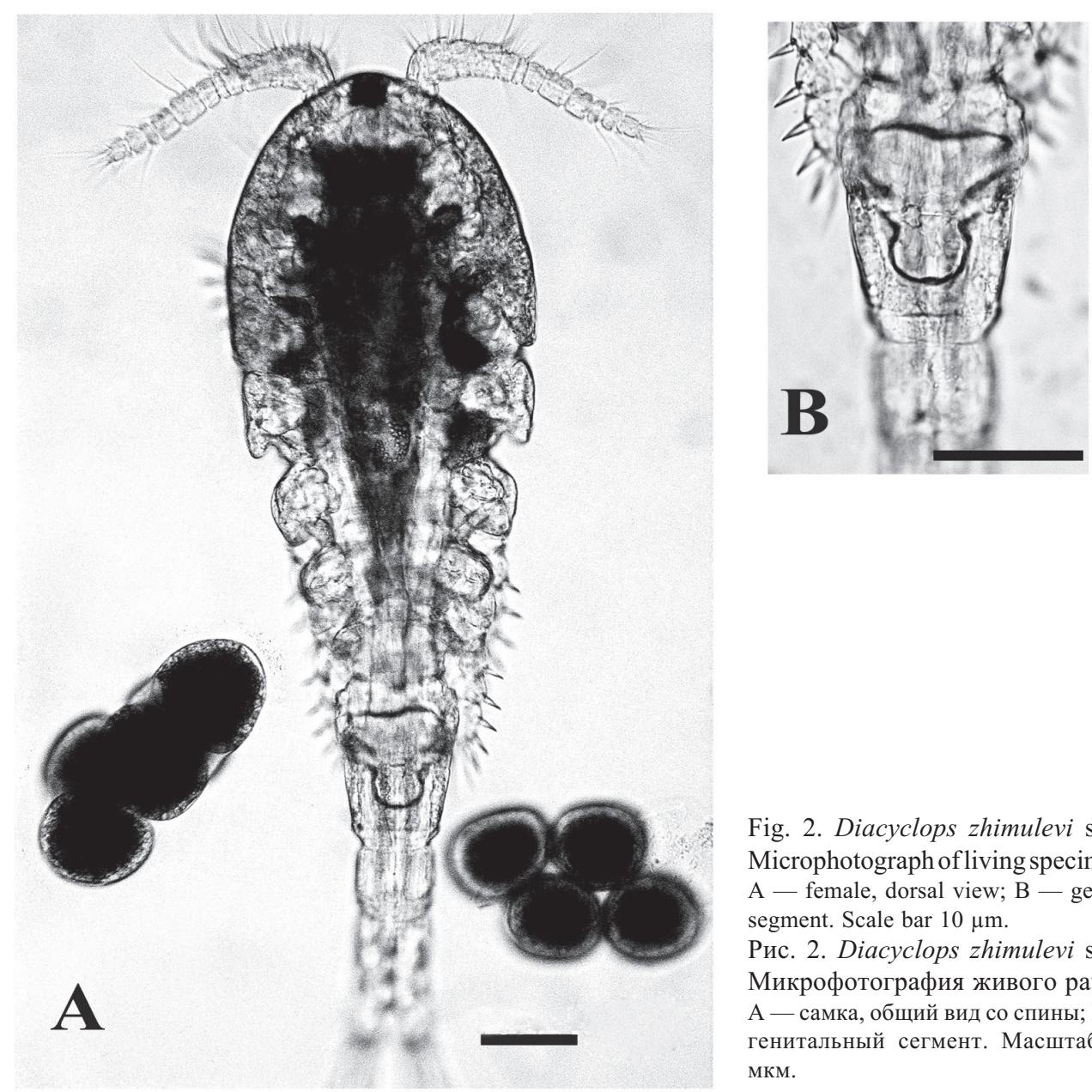

Fig. 2. Diacyclops zhimulevi sp.n. Microphotograph of living specimen. A - female, dorsal view; B - genital segment. Scale bar $10 \mu \mathrm{m}$.

Рис. 2. Diacyclops zhimulevi sp.n. Микрофотография живого рачка. А - самка, общий вид со спины; В генитальный сегмент. Масштаб 10 мкм.

being alive (immediately after collection) and after fixation. Individuals were fixed in $4 \%$ formaldehyde (19 specimens) or $70 \%$ ethanol (20 specimens) in separate tubes. Fixed specimens stained with an aqueous solution of fuchsin were used for fully dissected preparations of all body parts. We used two types of permanent preparations: (1) in Faure-Berlezet fluid and (2) in glycerol and ringed with Canada balsam. The copepods were photographed using Meiji and Nikon microscopes (Japan) equipped with a digital camera (Olympus CAMEDIA) with a universal adaptable photographic block(NY2000S). Illustrations were made using a Nikon "camera lucida" together with $40 \times$ and $100 \times$ objective lenses. All of the materials including type specimens, original drawings and a digital image data-base (over 500 photos of the external appearance of living and fixed specimens and details of dissected preparations) are stored in the collection of the Laboratory of Biology of Aquatic Invertebrates at the Limnological Institute SB RAS, Irkutsk (curator of the cyclopoid collection - N.G. Sheveleva).

\section{Systematic}

Diacyclops zhimulevi Sheveleva et Timoshkin sp.n.

Figs 1-4.

TYPE MATERIAL. Holotype (Catalogue Number 1130): whole mounts No.1 (female carrying eggs) and 

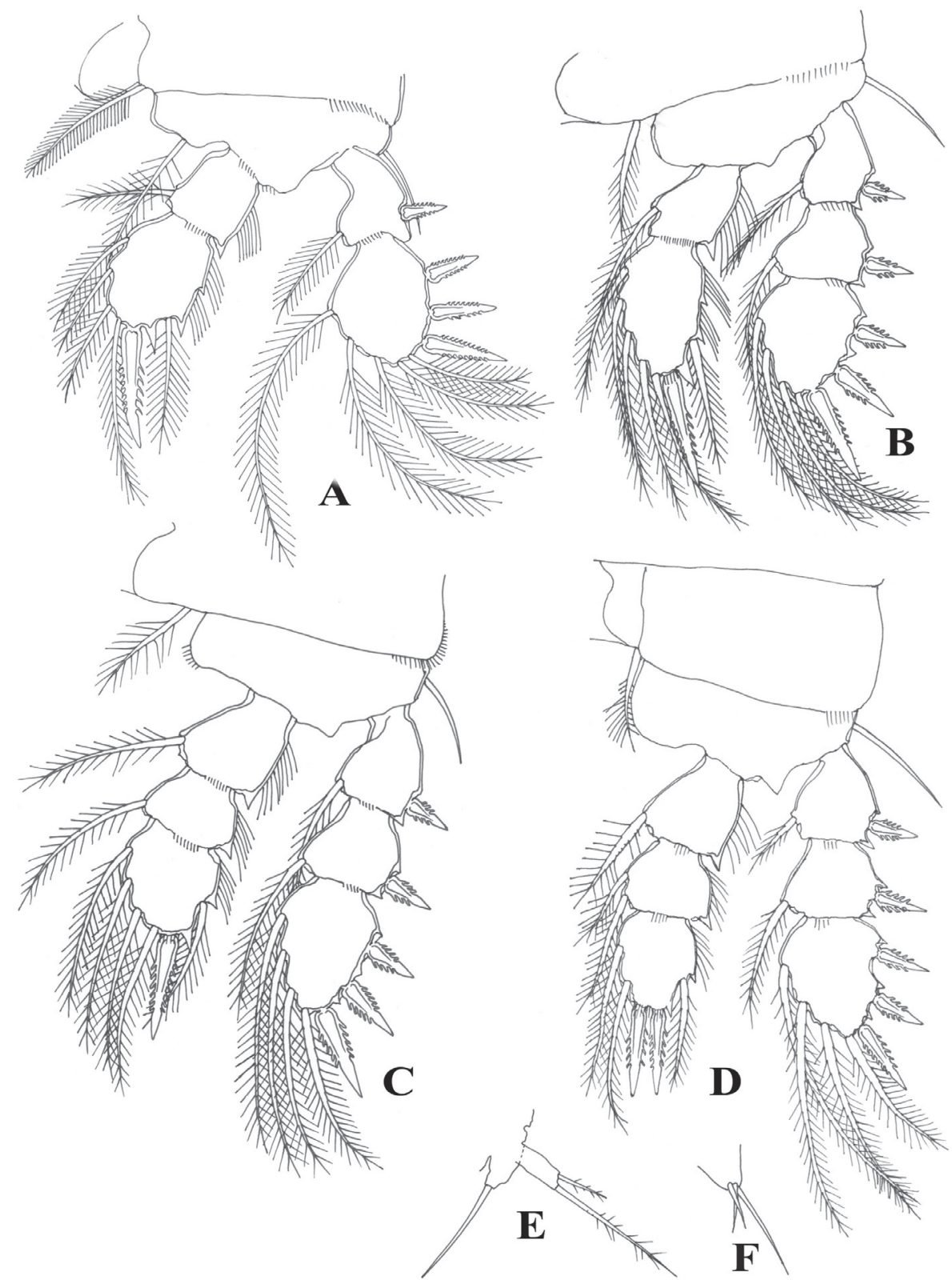

Fig. 3. Diacyclops zhimulevi sp.n. Swimming legs of female (P1-P4), posterior view, and legs of female and male.

$\mathrm{A}$ - P1; B - P2; C - P3; D - P4; E - P5 (female); F - $\mathrm{P}_{6}$ (male). Scale bar $50 \mu \mathrm{m}$.

Рис. 3. Diacyclops zhimulevi sp.n. Плавательные ноги самки (Р1-Р4), вид сзади, и ноги самки и самца. A - P1; B - P2; C - P3; D - P4; E - P5 (самка); F — P6 (самец). Масштаб 50 мкм. 

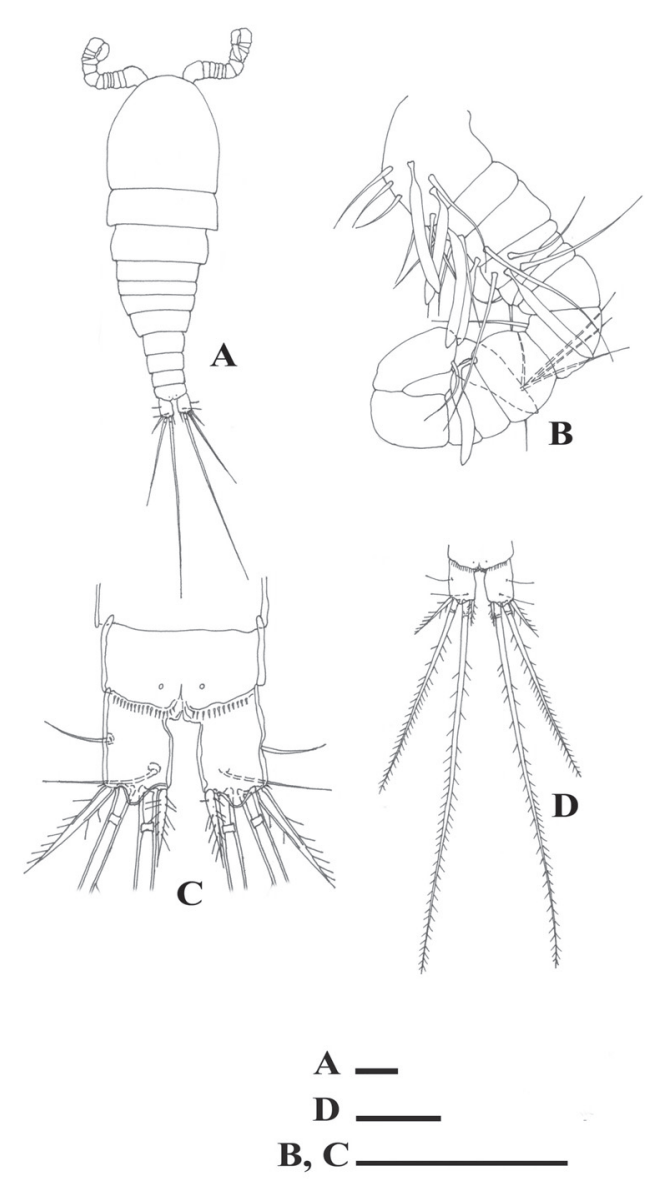

Fig. 4. Diacyclops zhimulevi sp.n., paratype, male. A - dorsal view; B - antennule; $\mathrm{C}$ - anal somite, dorsal view; D - anal somite and caudal rami, dorsal view. Scale bar $50 \mu \mathrm{m}$.

Рис. 4. Diacyclops zhimulevi sp.n., паратип, самец. А - общий вид, со спины; В - антеннула; С анальный сегмент, со спины; D - анальный сегмент и каудальные ветви, со спины. Масштаб 50 мкм.

allotype No. 1A (male) on slides in Faure-Berlezet fluid; specimens collected on 29 June 2006 in Bolshye Koty Bay at a depth of $0.6 \mathrm{~m}$ from sand. Paratypes: fixed in $4 \%$ formaldehyde solution, Nos 1-10 (females) and Nos 1120 (males) collected at the same locality and taken from the same sample as that of the holotype. Holotype, allotype and paratypes deposited to the Laboratory of Biology of Aquatic Invertebrates at the Limnological Institute SB RAS, Irkutsk. Two paratype males and 2 paratype females sent to the Zoological Museum of Moscow State University.

TYPE LOCALITY. Sandy bottom in the shallow littoral zone of Bolshye Koty Bay, southwestern Lake Baikal opposite the station of the Limnological Institute SB RAS.

ETYMOLOGY. The species is named in honour of Academician Igor Fedorovich Zhimulev (Institute of Cytology and Genetics, Siberian Branch of RAS, Novosibirsk), who initiated a new stage in the investigation of the ecology, systematics and molecular biology of the cyclopoid fauna in Lake Baikal.

DESCRIPTION. Female (holotype) Body length (excluding furcal setae) $380 \mu \mathrm{m}$. Body stout, translucent, harpacticoid-shaped, pale reddish-brown. Cephalothorax broad, its length almost equal to its width (Fig. 1A), thoracic segments with lateral notches (well-defined only in living specimens (Fig. 2) and caudally directed, rounded lateral angles. Posterior angles of thoracic segments 2, 3 and 4 of the same structure, and these segments clearly separated from each other (Fig. 2A).

Antennule relatively short, 11-segmented, not reaching posterior margin of cephalothorax, bearing plumose setae of various lengths (Figs 1B-2A). Antenna 4-segmented with 6 setae on distal end, 2 of them strong and claw-like (Fig. 1C). Labrum with 13-14 teeth (Fig. 1D), mandible with 3 setae, 1 of which very short and other 2 equal and long (Fig. 1E), external margins of maxilliped smooth (Fig. 1G).

Abdomen relatively long, $35 \%$ of the body length. Seminal receptacle consisting of a large, broad, oval anterior part and a rounded sac posteriorly. Width of posterior part $40-50 \%$ that of anterior part (Figs 1I, 2B). Longitudinal row of short spinules on posterior margin of anal somite (Fig. 1K, J). Caudal furca very short, length:width ratio close to $1: 1$ (Table 1). Rami slightly divergent, their inner margins without hairs. Lateral seta inserted at about midlength. Outer spicular apical seta evenly armed with long hairs starting from its base. Dorsal seta long, slender, its length twice the width of the caudal furca. Inner apical seta less stout than outer one and somewhat shorter than outer seta (Table 1), bearing long hairs starting from its base. Inner medial seta long, stout, on average 1.71 times longer than outer medial seta (Table 1). Both setae showing heterono- 
Table 1. Number of spines and setae on swimming legs 1-4 (P1-P4) in Diacyclops zhimulevi sp.n. Таблица 1. Количество шипов и щетинок на плавательных ногах 1-4 (P1-P4) Diacyclops zhimu-

levi sp.n.

\begin{tabular}{|c|c|c|c|c|}
\hline $\begin{array}{c}\text { Leg } \\
\text { (Нога) }\end{array}$ & $\begin{array}{c}\text { Coxa } \\
\text { (Кокса) }\end{array}$ & $\begin{array}{c}\text { Basis } \\
\text { (Базис) }\end{array}$ & $\begin{array}{c}\text { Endopod } \\
\text { (Эндоподит) }\end{array}$ & $\begin{array}{c}\text { Exород } \\
\text { (Экзоподит) }\end{array}$ \\
\hline P1 & $0-1$ & $1-1$ & $0-1 ; 1-5$ & $1-1 ; 3-5$ \\
\hline P2 & $0-1$ & $1-1$ & $0-1 ; 1-6$ & $1-1 ; 1-1 ; 3-4$ \\
\hline P3 & $0-1$ & $1-1$ & $0-1 ; 0-1 ; 1-5$ & $1-1 ; 1-1 ; 3-4$ \\
\hline P4 & $0-1$ & $1-1$ & $0-1 ; 0-2 ; 2-3$ & $1-1 ; 1-1 ; 3-4$ \\
\hline
\end{tabular}

mous and rather sparse, plumose ornamentation covering whole distal surface, or $4 / 5$ of their length (Fig. 1K).

Segmentation of swimming legs $1-4$ (P1P4): 2.2/3.2/3.3/3.3; spine formula $3 / 3 / 3 / 3$ and seta formula $5 / 4 / 4 / 4$ (Fig. $3 A-D$ ). Setae on all segments of different lengths and bilaterally plumose. Distal endopodal segment of P1 and $\mathrm{P} 2$ bearing 1 very strong spine almost as long as the segment, this spine minutely serrate on both sides. Distal endopodal segment of P4, 1.3 times longer than broad (Fig. 3D) and armed with 2 spines of nearly equal length (or inner spine slightly longer than outer one). P5 with elongate basis not articulating with the somite and armed with thin seta (Fig. 3E), and rectangular exopodal segment with a terminal spine and seta, the spine being twice as long as segment's width (Fig. 3E).
Egg sacs attached to genital segment ventrally and containing 5 eggs each, these 50-60 $\mu \mathrm{m}$ in diameter.

Male. Length, colour and shape of body similar to female (Fig. 4A).

Antennule of male 14-segmented (Fig. 4B). Segmentation of swimming legs, as well as spination and setation of distal segments of exopods, similar to those in females (Fig. 3). Spermatophores bean-shaped. Furcal rami of male very slightly shorter than those of female, and square in shape (length:width ratio about 1:1) (Fig. 4D).

DIAGNOSIS. The new species differs from its most closely related species, $D$. eulitoralis, by a contrasting combination of characters: shorter, nearly square caudal furca (furcal index 1:1 in contrast to $1: 3.5$ in $D$. eulitoralis) and a different segment pattern of the swimming legs

Table 2. Main biometric indices of Diacyclops zhimulevi sp.n. from the littoral zone of southern Lake Baikal.

Таблица 2. Основные биометрические показатели Diacyclops zhimulevi sp.n. из литорали южной части озера Байкал.

\begin{tabular}{|c|c|}
\hline $\begin{array}{c}\text { Index } \\
\text { (Индекс) }\end{array}$ & Mean \pm S.D. \\
\hline $\begin{array}{l}\text { Female body length, } \mu \mathrm{m} \\
\text { (длина тела самки, мкм) }\end{array}$ & $0.32 \pm 0.06$ \\
\hline $\begin{array}{l}\text { Body length / cephalothorax width } \\
\text { (Соотношение длины тела и ширины цефалоторокса) }\end{array}$ & $3.41 \pm 0.13$ \\
\hline $\begin{array}{l}\text { Furcal length / width } \\
\text { (Фуркальный индекс) }\end{array}$ & $1.03 \pm 0.02$ \\
\hline $\begin{array}{l}\text { Apical inner / outer setae length } \\
\text { (Соотношение длин апикальной внешней и апикальной внутренней щетинок) }\end{array}$ & $1.23 \pm 0.01$ \\
\hline $\begin{array}{l}\text { Apical inner seta / caudal ramus length } \\
\text { (Соотношение длины внутренней апикальной щетинки и длины фурки) }\end{array}$ & $0.9 \pm 0.02$ \\
\hline $\begin{array}{l}\text { Apical outer seta / body length } \\
\text { (Соотношение длины внешней апикальной щетинки к длине тела) }\end{array}$ & $0.08 \pm 0.005$ \\
\hline $\begin{array}{l}\text { Medial inner / outer seta length } \\
\text { (Соотношение длин средней внутренней и средней внешней щетинок) }\end{array}$ & $1.71 \pm 0.02$ \\
\hline
\end{tabular}


1-4: $2.2 / 3.2 / 3.3 / 3.3$, compared to $2.2 / 3.2 / 3.2 /$ 3.2 in $D$. eulitoralis. The armament of the distal endopodal segments of $\mathrm{P} 1$ and $\mathrm{P} 2$, which is generally characterized by a long and strong apical spine. The two species are also clearly divergent in their ecology and habitat: $D$. eulitoralis inhabits the upper surf zone of the beach and may fairly be called an interstitial species (Alekseev \& Arov, 1986; Boxshall et al., 1993), whereas the new species colonizes sandy bottoms of the littoral zone proper.

DISTRIBUTION AND BRIEF NOTES ON THE ECOLOGY. D. zhimulevi sp.n. is abundant in the shallow littoral zone of southwestern Lake Baikal at depths of 0.6 to $4-5 \mathrm{~m}$ : on the sandy substrates of Bolshye Koty Bay and Chernaya Pad, in the vicinity of Berezovy Cape, opposite Mount Slyudyanka and at Marituy Settlement. Single mature females and, to a greater extent, males were encountered in epibenthic samples collected in early and midMay, and individuals showed highest abundances by the end of July. It is possible that this species is common on sandy bottoms of the whole littoral, at least in the southern area of Lake Baikal.

\section{Acknowledgements}

This work was partially supported by the Integration Project of the Siberian Branch of the Russian Academy of Sciences (SB RAS) No. 37, "Molecular mechanisms of excessive DNA formation...»; Integration Project of SB RAS No. 49 "Diversity, biogeographical ties...»; our studies were carried out as part of State Project No. 7.9.1.3, "Impact of landscape ecology on the formation of biodiversity, unique communities and speciation in the shallow waters of Baikal" (2007-2009). The authors are grateful to Janet W. Reid, Ph.D., (JWR Associates, USA) for her kind support and recommendations, especially in morphological description of the species mouth parts. We thank the Head of the Limnological Institute Station SB RAS in Bolshye Koty Settlement, Dr. A.L. Novitsky, for assistance in field work, and also I.V. Khanaev for diving and collecting samples. The English version of this paper was prepared by E.M. Timoshkina. Special thanks are offered to Dr. M.J. Grygier (Lake Biwa Museum, Japan) for checking the text.

\section{References}

Alekseev V.A., Arov I.V. 1980. [A new cyclopoid of the genus Diacyclops (Crustacea, Copepoda)] // Zoologicheskiy Zhurnal. Vol.65. No.7. P.1084-1087 [in Russian, with English summary].

Boxshall G.A., Evstigneeva T.D., Clark P.F. 1993. A new interstitial cyclopoid copepod from a sandy beach on the western shore of Lake Baikal, Siberia // Hydrobiologia. Vol. 268. P.99-107.

Flossner D. 1984. Two new species of the genera Acanthocyclops and Diacyclops (Crustacea, Copepoda) from Lake Baikal // Limnologica. Vol.15. No.1. P.149156.

Mazepova G.F. 1978. [Cyclopoids of Lake Baikal]. Novosibirsk: Nauka. 142 p. [in Russian].

Mazepova G.F. 2001. [Cyclopoids (Cyclopoida)] // O.A. Timoshkin (ed.). Index of animal species inhabiting Lake Baikal and its catchment area. Lake Baikal. Vol. 1. Book 1. Novosibirsk: Nauka. P.451-467 [in Russian].

Timoshkin O.A., Suturin A.N., Kravtsova L.S., Kulikova N.N., Malnik V.V., Sitnikova T.Ya., Obolkina L.A., Sheveleva N.G., Rozhkova N.A., Melnik N.G., Slugina Z.V., Proviz V.I., Evstigneeva T.D., Logacheva N.F., Bondarenko N.A., Paradina L.F., Shirokaya A.A., Maksimova N.V., Zaytseva E.P., Nepokrytykh A.V., Parfenova V.V., Kostornova T.Ya., Boyko S.M., Penzina M.M., Poberezhnaya A.E., Semiturkina N.A., Basharina T.V., Potapskaya N.V. 2008. [Main results of interdisciplinary investigations, performed on the ecological test site Berezovy (Southern Baikal) within 2000-2007 with special reference on the biodiversity, productivity of shallow water zone benthos of the lake and main factors, influencing them] // Proceedings of the Research Conference "Evolution of Life in the Process of Abiotic Changes on the Earth". Novosibirsk: SB RAS Publishers. P.344-357 [in Russian].

Responsible editors: V.N. Ivanenko, F.D. Ferrari 